Os anos de exílio do jovem Mallarmé. Joaquim Brasil Fontes (Cotia, SP: Ateliê Editorial, 2007, 176 p.)

\title{
O jovem Mallarmé
}

É de se comemorar o lançamento de mais um livro crítico sobre a obra deste poeta ainda tão pouco estudado no Brasil, Stéphane Mallarmé. Um dos ícones da modernidade poética na França, ao lado de Baudelaire, Rimbaud e Verlaine, Mallarmé é responsável por uma revolução poética que abriu caminhos e possibilitou as vanguardas do século $\mathrm{XX}$, do futurismo ao surrealismo, passando também pelo estruturalismo e por Blanchot.

Depois da sua apresentação ao público brasileiro pelos poetas concretistas, no Mallarmé, que apresenta traduçôes de alguns poemas, além de ensaios críticos, foram necessárias décadas até que uma obra como Os anos de exílio do jovem Mallarmé, de Joaquim Brasil Fontes, aparecesse. $\mathrm{O}$ autor propõe uma leitura da obra de juventude do poeta, realizada nos anos anteriores a sua chegada a Paris, ou seja, até os anos 1870 , apresentando, além disso, parte da obra em prosa do poeta, traduzida pela primeira vez no Brasil.

Se a leitura concretista celebra o Mallarmé responsável pela revolução da linguagem poética, um Mallarmé da modernidade, modernidade que é ainda a de nossos dias, Joaquim Barros Fontes vem, neste livro, iniciar o leitor brasileiro na descoberta de um outro Mallarmé. Não aquele que se arriscou no recém-lançado verso livre, dos debates sobre o simbolismo dos anos 1880, mas o jovem leitor de Hugo e Musset, ou um outro de "Les Fleurs" e "Brise Marine", sob a influência de Baudelaire. Poeta "spleenético", entediado. Um Mallarmé que não é apenas o poeta do poema em estado puro, mas o escritor do elegante jornal La dernière mode [A última moda] e dos Vers de cirsconstance [Versos de circunstância].

Joaquim Brasil Fontes segue uma linha já claramente distinta da crítica mallarmeana, aquela que pretende ler a obra do poeta a partir da que ele não escreveu, do tão comentado "Livro". Mallarmé poeta do "Livro" jamais escrito. Um poeta idealista assombrado pelo "azur", ou ideal, poeta para quem, como define Pedro Meira Monteiro no prefácio da obra, "a precisão da forma é um nunca-acabar". Assim, este eterno devir do "Livro" (leitura de Mallarmé que propōe

+ (Campos, A. et al. São Paulo: Editora Perspectiva, 1974.) 
Blanchot em seu "Livro por vir") inspira o crítico e guia sua leitura de Mallarmé assim como dita a forma de seu ensaio, o fragmento.

$\mathrm{O}$ autor sublinha a dificuldade de leitura e de interpretação crítica de Mallarmé, e se pergunta "se nossa primeira abordagem do texto de Mallarmé já não será sempre, por definição, impura, elaborando-se numa trama de pequenos saberes e leituras clássicas, de topoi como o da obscuridade, indissociáveis da própria obra e que não podem, portanto, ser colocados entre parênteses [...], sob o risco de aniquilar o objeto de estudo, ele próprio". Assim, poderíamos dizer, com o autor, que Mallarmé já é, de antemão, um outro.

A poesia de Mallarmé, além de ser obscura, era de difícil acesso, para dizer o mínimo. Até meados da década de 1880 o poeta publicou apenas alguns poemas esparsos em revistas da época, uma edição de L'après-midi d'un faune, e Le corbeau, ambas luxuosas (caras) e em pequena tiragem. Já a primeira edição de Poésis foi organizada pelo poeta, mas publicada apenas postumamente. Ou seja, Mallarmé era muito pouco conhecido dos poetas e críticos de seu tempo, sua consagração poética tendo ocorrido mais tarde. Assim parte da má compreensão da qual o poeta foi vítima em seu tempo, e que contribui para a construção do mito de um poeta obscuro, se explica pela pouca quantidade de poemas publicados e divulgados na imprensa de seu tempo.

Além disso, circulava na imprensa da época o desejo mallarmeano de escrever o "Livro", arquitetado, premeditado e definitivo. Criou-se, assim, uma imagem paradoxal do poeta, por um lado, o escritor do "Livro", por outro, um poeta sem obra, glorificado por alguns poetas como um grande poeta e incompreendido pelos críticos.

O segundo capítulo segue a exploração deste poeta que se tornou mito, apresentando descrições e retratos do poeta, pintados ou escritos, por amigos e colegas como Valéry, Manet e Regnier. Encontram-se aí depoimentos sobre o poeta, sua personalidade, descrições de seu tipo físico, etc, bem como trechos de um relato autobiográfico e comentários de críticos como Mauron, seu primeiro biógrafo, e Sartre. Fontes apresenta, assim, ao leitor o Mallarmé das terças-feiras, anfitrião da Rue de Rome. Além do homem, pai, marido e professor de inglês. Ao fazer um retrato autobiográfico, que não colabora para a melhor leitura e análise crítica do texto mallarmeano, mas que se distancia do texto, procurando um autor, Fontes cria um personagem: "um desconhecido com 21 anos de idade", situado "na moldura banal de um quadro pequeno burguês".* 
"Torpor, tédio, alma enfraquecida e lassa, o jovem Mallarmé morre aos poucos numa cidadezinha de província francesa”.

"Todo Mallarmé nestas primeiras cartas: por definição, o escritor, o poeta. $\mathrm{O}$ homem atento às coisas miúdas da vida. $\mathrm{O}$ hipocondríaco. O exilado.”* É dessa maneira que o autor descreve o Mallarmé dos três anos vividos em Tournon. Assim, o spleen baudelairiano se transforma no tédio da vida de província, a biografia do poeta serve de base para a aproximação teórica da obra, reduzindo toda uma poética da negatividade, da crítica, a representação, a um estado "psicológico".

Fontes poderia explorar a idéia de exílio como metáfora, ou seja, sem criar um exílio de Mallarmé que de fato não existia. $\mathrm{Na}$ década de 1850, o exílio "poético" adquire uma enorme relevância, quando Victor Hugo, poeta, deputado, enfim, como Mallarmé o descreve em Crise de vers, "divindade" e "monumento" da poesia francesa, se auto-exila depois do fracasso da revolução de 1848 e do golpe de Napoleão III, que a sucedeu. Com Victor Hugo toda a poesia se encontra exilada, excluída da cena política e social francesa. São os anos do "desencantamento" que geraram poetas como Baudelaire, Flaubert e, entre eles, Mallarmé. Assim, reduzir a poesia mallarmeana a uma "frieza", fazer de Mallarmé um poeta "isolado na província" é renegar toda a dimensão crítica que a literatura das geraçôes de 1830 e 1840 possuía. De fato, a "frieza" e a "delicadeza" mallarmeanas não são tão evidentemente críticas quanto os poemas mais irônicos e violentos de Baudelaire. Resta ao leitor ler na poesia, através dela, formalmente, a crítica à sociedade capitalista, que se inscreve através de uma crítica da representação, do real, que é crítica ao trabalho abstrato, ao valor abstrato do dinheiro, crítica à imprensa, que comercializa a literatura e faz dela um produto como qualquer outro etc.

Felizmente ainda se trata de poesia. Fontes destaca uma certa "delicadeza", que seria a marca da relação que o poeta estabelece com os outros e com o verbo. Com relação ao texto Le démon de l'analogie [O demônio da analogia], Fontes ${ }^{*}$ destaca a influência de Poe sobre Mallarmé; do Poe de "Filosofia da composição", para quem o poema deve ser um "trabalho realizado conscientemente sobre o significante; sobre a forma e a estrutura do texto". Segundo o autor, o poema parece estar situado "nos antípodas mesmo da experiência analisada por Poe", já que ele mostra um homem, um poeta, diríamos, assombrado por um refrão que ele tenta, em vão, exorcizar. 
(p. 108)

- (Structure de la poésie moderne. Paris: LGF, 1999.) (p. 125)

(p. 129)
O capítulo termina com os anos da famosa crise do poeta, que ocorre por volta de 1869, provocada pela escrita de Hérodiade e que desemboca na escrita, inacabada, do conto Igitur. "Nessa crise e através dela 'delineia-se' um jogo de conflitos insolúveis que procedem da contradição original entre Ser e Nada: arte/vida, imaginação/realidade, intelecto/emoção - o poeta aproxima-se desse ponto que passará a ser o centro móvel de sua obra, marcada paradoxalmente pela presentificação da ausência."

Fontes retoma a idéia de Friedrich ${ }^{*}$ para quem a poesia mallarmeanna opera a presentificação da ausência e a dissolução da presença, idéia que não parece estar à altura do poeta que tinha a destruição como musa inspiradora, que ao enfrentar o acaso encontrou o absurdo e a loucura, para finalmente poder lançar os dados e navegar em direção à Idéia. Não se trata de um jogo de contrários, mas de uma inversão de valores. Mallarmé afirma em seu poema "Um lance de dados" a força criadora do acaso, a positividade da negação, assim, a ausência, como nomeada por Friedrich, ou a dissolução, como preferimos chamá-la, se torna a única forma possível da Idéia, do poema, um movimento infinito, sempre se construindo, e reconstruindo pela leitura.

Finalmente, no quarto capítulo, Fontes confronta duas tentativas de explicação e compreensão do poema "Soneto em yx", empreendidas por MacIntyre e Octávio Paz.

$\mathrm{O}$ autor sublinha que as duas interpretações têm algo em comum, ambas giram "obsessivamente em torno da questão fundamental do sentido". " O autor pergunta: "Não seria a obsessão, em suma, de encontrar o sentido primeiro desse soneto o que o transforma literalmente num enigma, num falar encoberto exigindo decifração?”*

Essa pergunta pode ser também compreendida como a elaboração de uma hipótese que explicaria a tal "obscuridade" dos poemas mallarmeanos. Ela seria uma invenção da crítica, que tenta sempre procurar os sentidos da obra deixando de lado o que seria a questão fundamental da poesia mallarmeana. Fontes, porém, não desenvolve a questão, que continua em aberto. Tudo o que podemos afirmar é que a via interpretativa não seria a melhor abordagem pra o texto mallarmeano.

Assim, mais do que apresentar a obra de Mallarmé, Fontes se engaja num esforço de compreensão e com ele engaja também a crítica brasileira. Se o esforço interpretativo é vão, se não estamos 
tratando de sentido, de que trataríamos então? O autor nos deixa algumas pistas. Ele ressalta que a poesia se faz através de jogo entre as palavras e entre as relaçôes que elas estabelecem umas com as outras no interior do poema. Mallarmé é um poeta que cede a iniciativa às palavras. Cabe, portanto, aos críticos responder a essas e a outras perguntas. Nesse caso, os dados já foram lançados.

Larissa Drigo Agostinho (Mestranda em Lettres Modernes, Universidade de Paris IV) 